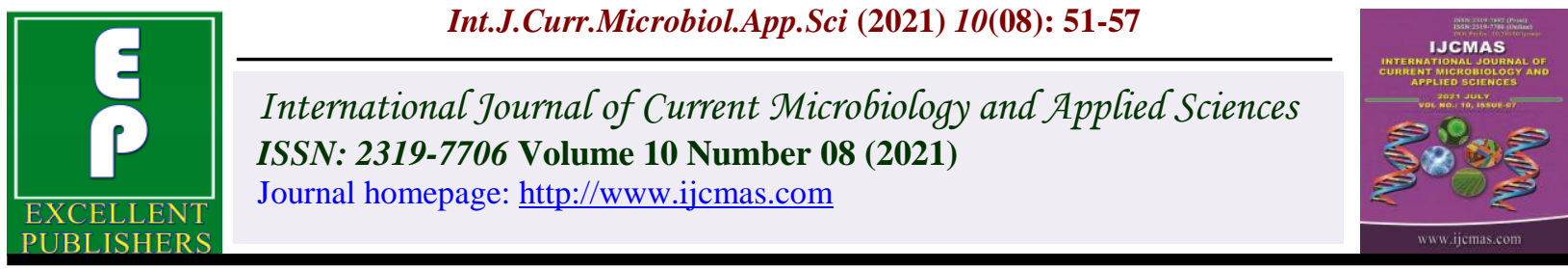

\title{
Mycorrhizal Inoculation affects the Biochemical Composition of Echinacea
}

\author{
Asha Sharma ${ }^{1}$, Bandi Arpitha Shankar ${ }^{2 *}$ and Ishan Saini ${ }^{3}$ \\ ${ }^{1}$ Department of Agroforestry, G. B. Pant University of Agriculture and Technology, \\ Pantnagar, Uttarakhand - 263145, India \\ ${ }^{2}$ Acharya N G Ranga Agricultural University, Tirupati- 517502, Andhra Pradesh, India \\ ${ }^{3}$ Department of Botany, Kurukshetra University, Kurukshetra 136118, Haryana, India \\ *Corresponding author
}

\section{A B S T R A C T}

Keywords

Echinacea,

Heliantheae,

Asteraceae,

Echinacea

angustifolia

Article Info

Accepted:

10 July 2021

Available Online:

10 August 2021
Medicinal plants contain a wide variety of bioactive compounds. Echinacea (Asteraceae) is a North American native plant that is well-known for its use in the treatment of a wide variety of ailments. Medicinal herbs such as Echinacea have been used to treat a wide variety of diseases since ancient times. Here we studied the effect of arbuscular mycorrhizal fungi (AMF) inoculation on physiological and mycorrhization characteristics of Echinacea. The physiological and mycorrhization characteristics (Root essential oil, ABTS Antioxidant, FerricReducing Antioxidant, Total phenolic, AM Spore No., AM Root Colonization) both are higher under mycorrhizal association than the control plants of different echinacea species. E. purpurea showed greater results than the E. angustifolia and E. pallida. Physiological and mycorrhizal traits were significantly higher under $E$. purpurea than the other species. E. purpurea showed higher AM Spore No., AM Root Colonization 231.30, $78.70 \%$ respectively. Lowest physiological and mycorrhization characteristics were found under E. pallida. The result of mycorrhizal association was very effective for plant growth and increased biophysicochemical properties than the control plants.

\section{Introduction}

Medicinal plants are a source of a wide range of bioactive compounds (1-3). In this direction, Echinacea (Heliantheae, Asteraceae) is a North American native herb that is wellknown for its use in treating a wide variety of diseases(4). Medicinal plants like Echinacea that are used on daily basis are employed to treat a wide variety of illnesses from a long time $(5,6)$. In Europe and North America, various preparations of Echinacea are widely used as herbal medicines to prevent and treat the common cold, the flu, upper respiratory tract infections, and a variety of other diseases and conditions (7). 
In Europe, America, and Canada, the plants are cultivated for phytomedicine, nutritional supplements, and natural health products and even new approaches are being adapted to increase the content of bioactive compounds of in the already cultivated popular plants $(8$, 9). Echinacea purpurea (L.) Moench, Echinacea pallidavar. pallida (Nutt.), and Echinacea angustifolia (DC.) are three Echinacea species that are used in commercial medicinal formulations. Echinacea purpurea (L.) Moench, Echinacea pallida var. pallida (Nutt.), and Echinacea angustifolia () are believed to possess a variety of other pharmacological properties, including antiinflammatory efficacy (10). Echinacea species contain diverse active ingredients, including lipophilic compounds (alkamides, ketoalkenes, and ketoalkynes), and phenolic acids (phenolic acids) glycoproteins, and polysaccharides that is also affected by cultivation methods (11-13).

When it comes to the bioactive chemicals found in Echinacea species, alkamides are the most thoroughly studied (14). The roots of Echinacea purpurea and Echinacea angustifolia contain the highest concentrations of alkamides. The aerial parts of these plants, as well as the roots of E. pallida, have been shown to contain significantly less of this chemical (10). Bio-inoculants such as arbuscular mycorrhizal fungi may remain a viable method of increasing plant growth and production while also increasing plant tolerance to biotic and abiotic stresses (1518). It is critical to remember that shifting dynamics, a complex of their development, and a heterogeneous mix of components in the finished device can all contribute to a biosuccess inoculant's by providing a unique sequence of activities (19).

The issue is further complicated by the long life of plants, the use of bio-inoculants, and the presence of a diverse range of components in the spectrum of growing bio-inoculants. Any bio-inoculant results in the synergistic action of numerous large bioactive compounds and mineral nutrients (20). When used properly, these techniques work to develop a defensive reaction alongside matter in response to environmental changes that have the potential to impair plant development irreversibly $(21,22)$. The possible trade-off between growth and acclimation metabolisms results in a form of physical exercise for plant life, as energy and nutrients normally devoted to development are redirected to stressresponsive systems, and newspapers are generated to support these activities.

Abiotic stresses have evolved over time as a result of farmers' experiences, technological advancement, climate change, and scientific knowledge. Agronomic management has resulted in increased resilience to abiotic stressors. The quantity of the appropriate cultivar, the optimal acquisition time, the sowing density, and, of course, the amount of water and fertilizer used are all critical considerations (23-25). Crop production in a protected environment is a method of farming that protects plants from harmful environmental conditions (26). In light of this overview, this study makes recommendations regarding the use of bio-inoculants, their benefits for Echinacea.

\section{Materials and Methods}

\section{Experimental Setup}

The current experiment took place between April and August of 2020 using a completely randomized block design. Ten days later, the plants were transplanted. It was grown in soil containing AMF, Glomus mosseae (which contained $82-86 \%$ colonized root pieces and 620-630 AM spores per $100 \mathrm{~g}$ ), and Gigantean spores (which contained 620-630 AM spores per $100 \mathrm{~g}$ ) (having 70-74 percent 
colonized root pieces and 500-520 AM spores per $100 \mathrm{~g}$ ). Each AMF was mass replicated in greenhouse conditions for 90 days using a sterile sand soil mixture (1:3) and Maize as the host plant. To ensure their survival as an obligatory symbiont, AMF is propagated as endomycorrhizal species. The native density of mycorrhizal spores in the experimental location was $24.57 \% 10 \mathrm{~g}$ soil, as determined by the gridline intersect method applied to soil samples collected(27, 28). Bacillus subtilis (MTCC 1305) and Pseudomonas fluorescens. After 48 hours of culture in a nutritious broth medium.

\section{Field preparation}

Each species has a separate control flowerbed that is kept inoculum-free. On the other hand, other regions were treated with consortium therapy, as it has been demonstrated that consortium therapy stimulates flowering plant growth and development. At a $65-67 \%$ rate, $\mathrm{G}$. mosseae colonized maize roots $(1 \mathrm{~cm})$ and spores (610-630 spores per $100 \mathrm{~g}$ of corn rhizospheric soil). G. gigantea-colonized maize roots $(1 \mathrm{~cm})$ and 580-600 spores (per $100 \mathrm{~g}$ of Maize rhizospheric soil) were used in the inoculation, along with $B$. subtilis and $P$. fluorescens.

The initial bacterial infection occurred during seedling planting in the flowerbed by simply dipping the seedlings' roots in the appropriate broth medium for ten minutes.

After 10-13 days, when the plantlets had formed their roots (approximately $10 \mathrm{~mm}$ ), a second treatment with $G$. mosseae and $G$. gigantea was applied by burying additional Maize rhizospheric soil around the roots to ensure that the inoculum was established effectively. Similarly, the second treatment of B. subtilis and P. fluorescens was carried out similarly, with media being sprinkled around the bacteria's roots.

\section{Characteristics}

Ten randomly selected plants from each plot were evaluated 90 days after inoculation (DOI), out of a total of fifteen plants in each plot. The ferric-reducing antioxidant was determined using a modified version of the Farhat et al., method(29) (22). Wang et al., (23) the method was used to determine the total phenolic content. The antioxidant activity of ABTS, on the other hand, was determined using the Re et al., (30) method. The Mazza and Cottrell hydrodistillation method was used to determine the root's total essential oil content(31). Using Trypan blue staining, we developed and quantified mycorrhization 6570 days after inoculation. Additionally, the amount of AM spores produced and the percentage of roots colonized were determined using previously described and established procedures(32).

\section{Statistical analyses}

To ascertain differences in the means of each treatment, an analysis of variance (ANOVA) and a one-way ANOVA were conducted using the SPSS (11.5 version) software program. The results of the experiment were compared between control and microbial-inoculated plants using the least significant difference (LSD) (P0.05) method to determine the significance of the differences between the two groups.

\section{Results and Discussion}

Biophysical traits (Root essential oil, ABTS Antioxidant, ferric- reducing antioxidant and total phenolic) and mycorrhization pattern (AM spore, AM root colonization) were higher under consortium than the control plant (Table 1). Root essential oil was higher under E. purpurea $\left(0.61 \mathrm{ml} \mathrm{g}^{-1}\right)$ followed by $E$. angustifolia $\left(0.511 \mathrm{ml} \mathrm{g}^{-1}\right)$ and lowest in $E$. pallia $\left(0.47 \mathrm{ml} \mathrm{g}^{-1}\right)$ (Table 1). From Table 1 it 
is clear that biophysical attributes were higher under consortium than the control plant and $\mathrm{AM}$ spore no. and Am root colonization were also higher under mycorrhizal treatment than the control (Table 1). Among echinacea species. biophysical traits and mycorrhization pattern were higher in E. purpurea followed by $E$. Angustifolia lowest under E. pallida (Table 1). ABTS antioxidant was highest under E. purpurea $\left(24.98 \mathrm{~mm} \mathrm{ml}^{-1}\right)$ and followed by E. angustifolia and E. purpurea (23.16 $\mathrm{mm} \mathrm{ml}^{-1}$ ) (Table 2). E. purpurea showed the highest ferric- reducing antioxidant (0.99 nmol $\mu \mathrm{l}-1)$ and total phenolic (24.16 $\mathrm{mEAG} \mathrm{mL}^{-1}$ ) (Table 2). E. angustifolia and E. pallida showed ferricreducing antioxidants $0.90 \mathrm{nmol} \mu \mathrm{l}-1$, $0.85 \mathrm{nmol} \mu \mathrm{l}-1$ respectively.

Table.1 Changes in the physiological and mycorrhization characteristics of 3 different Echinacea species with/without mycorrhizal inoculation.

\begin{tabular}{|c|c|c|c|c|}
\hline Traits & Control & $\begin{array}{c}\text { Consortium } \\
\text { (Glomus mosseae+Giga } \\
\text { sporagigantean+Pseudomonas } \\
\text { fluorescence+ Bacillus subtilis) }\end{array}$ & $\begin{array}{c}\text { ANOVA (F2, } \\
\text { 27) }\end{array}$ & $\underset{(P \leq 0.05)}{\text { LSD }}$ \\
\hline \multicolumn{5}{|c|}{ Echinacea angustifolia } \\
\hline Root essential oil ( $\left.\mathrm{ml} \mathrm{g}^{-1} \mathrm{FW}\right)$ & $0.166 \pm 0.064^{\mathrm{b}_{\ddagger}}$ & $0.511 \pm 0.051^{\mathrm{a}}$ & 253.753 & 0.438 \\
\hline ABTS Antioxidant $\left(\mathrm{mm} \mathrm{ml}^{-1}\right)$ & $15.343 \pm 1.711^{b}$ & $23.164 \pm 1.425^{\mathrm{a}}$ & 791.887 & 1.214 \\
\hline $\begin{array}{l}\text { Ferric-Reducing Antioxidant } \\
\qquad(\mathrm{nmol} \mu \mathrm{l}-1)\end{array}$ & $0.429 \pm 0.125^{b}$ & $0.909 \pm 0.128^{\mathrm{a}}$ & 181.673 & 0.901 \\
\hline Total phenolic $\left(\mathrm{mEAG} \mathrm{mL}^{-1}\right)$ & $15.383 \pm 1.043^{\mathrm{b}}$ & $21.644 \pm 0.896^{\mathrm{a}}$ & 1.799 .164 & 0.707 \\
\hline AM Spore No. & $38.600 \pm 8.275^{b}$ & $221.300 \pm 8.069^{\mathrm{a}}$ & 552.277 & 4.754 \\
\hline AM Root Colonization $\%$ & $21.400 \pm 6.186^{b}$ & $74.200 \pm 6.442^{\mathrm{a}}$ & 2.758 .162 & 6.576 \\
\hline \multicolumn{5}{|c|}{ Echinacea purpurea } \\
\hline Root essential oil ( $\left.\mathrm{ml} \mathrm{g}^{-1} \mathrm{FW}\right)$ & $\begin{array}{c}0.1852 \pm 0.093 \\
\mathrm{~b}_{\ddagger}\end{array}$ & $0.613 \pm 0.123^{\mathrm{a}}$ & 207.758 & 0.082 \\
\hline ABTS Antioxidant $\left(\mathrm{mm} \mathrm{ml}^{-1}\right)$ & $14.903 \pm 2.061^{\mathrm{b}}$ & $24.982 \pm 2.129^{\mathrm{a}}$ & 495.176 & 1.571 \\
\hline $\begin{array}{l}\text { Ferric-Reducing Antioxidant } \\
\qquad\left(\mathrm{nmol} \mu \mathrm{l}^{-1}\right)\end{array}$ & $14.033 \pm 2.494^{b}$ & $0.999 \pm 0.174^{\mathrm{a}}$ & 426.688 & 1.631 \\
\hline Total phenolic $\left(\mathrm{mEAGmL}^{-1}\right)$ & $0.504 \pm 0.092^{b}$ & $24.167 \pm 1.805^{\mathrm{a}}$ & 62.778 & 0.104 \\
\hline AM Spore No. & $37.600 \pm 8.154^{b}$ & $231.300 \pm 9.849^{\mathrm{a}}$ & 997.800 & 11.368 \\
\hline AM Root Colonization \% & $\begin{array}{c}22.4000 \pm 4.97 \\
1^{\mathrm{b}}\end{array}$ & $78.700 \pm 5.618^{\mathrm{a}}$ & 858.682 & 3.974 \\
\hline \multicolumn{5}{|c|}{ Echinacea pallida } \\
\hline $\begin{array}{l}\text { Root essential oil (ml g-1 } \\
\text { FW) }\end{array}$ & $\begin{array}{c}0.153 \pm 0.068^{\mathrm{b}} \\
+\end{array}$ & $0.4711 \pm 0.064^{\mathrm{a}}$ & 613.859 & 0.051 \\
\hline ABTS Antioxidant $\left(\mathrm{mm} \mathrm{ml}^{-1}\right)$ & $13.603 \pm 1.719^{b}$ & $22.055 \pm 1.778^{\mathrm{a}}$ & 550.412 & 1.310 \\
\hline $\begin{array}{l}\text { Ferric-Reducing Antioxidant } \\
\qquad\left(\mathrm{nmol} \mu \mathrm{l}^{-1}\right)\end{array}$ & $13.528 \pm 1.114^{b}$ & $0.851 \pm 0.125^{\mathrm{a}}$ & 984.040 & 0.884 \\
\hline Total phenolic $\left(\mathrm{mEAGmL}^{-1}\right)$ & $0.339 \pm 0.137^{\mathrm{b}}$ & $19.765 \pm 1.241^{\mathrm{a}}$ & 104.020 & 0.098 \\
\hline AM Spore No. & $33.900 \pm 5.665^{b}$ & $195.200 \pm 7.871^{\mathrm{a}}$ & 3.445 .503 & 5.138 \\
\hline AM Root Colonization \% & $19.600 \pm 4.501^{\mathrm{b}}$ & $69.600 \pm 3.949^{\mathrm{a}}$ & 1.052 .777 & 3.179 \\
\hline
\end{tabular}


The total phenolic compound was lowest under E. pallida (19.76mEAG $\mathrm{mL}^{-1}$ ) (Table 1). The differences between the AM spore no., AM root colonization (\%) are illustrated in (Table 1).

Both the parameters werefound significantly higher under consortium than the control. AM spore no. was found highest in E. purpurea than the other species of echinacea (Table 1).AM spore no. E. angustifolia and $E$. purpurea were 221.30 and 231.30 respectively. AM root colonization is also higher under $E$. purpureathan the other echinacea species. AM root colonization was higher under E. purpurea depicted in (Table 1). E. angustifolia and E. pallida showed AM root colonization $74.2 \%$ and $69.6 \%$, respectively (Table 1).

Fertilizers were used to improve mycorrhizal inoculum and shoot biochemical composition. Echinacea species differed significantly in biochemical composition. Mycorrhizal fungi have been shown to benefit a variety of echinacea species (33).

Mycorrhizal fungus colonization of $E$. purpurea roots was comparable to other plants (34). Growing root colonization with biofertilizers may help plant roots contain higher levels of phenolic compounds like cynarin, cichoric acid, and caftaric acid. Biochemical fertilizers such as AMF and Pseudomonas species have increased plant growth and yield components.

AMF and phosphate solubilizing bacteria (PSB) outperformed other treatments in increasing plant nutrients, leaf relative water content, and reducing ion leakage $(23,35)$.

Medicinal values of any plant can be altered, this can also increase the economy of the country and even application of chemical fertilizers can be reduced. The result of mycorrhizal association was very effective for plant growth and increased biophysicochemical properties than the control plants. Out of the current tests, it might be recognized that the phytohormones are changed by bio inoculants, water uptake success in addition to photosynthetic activity.

\section{References}

1. P. Kaushik and S. Kumar: "Transcriptome analysis of bael (Aegle marmelos (L.) corr.) a member of family Rutaceae." Forests. vol. 9, no. 8, pp. 450, 2018.

2. P. Kaushik and S. Kumar: "Data of de novo assembly of the leaf transcriptome in Aegle marmelos." Data in brief. vol. 19, pp. 700-703, 2018.

3. P. Kaushik and S. Kumar: "Data of de novo assembly of fruit transcriptome in Aegle marmelos L." Data in brief. vol. 25, pp. 104189, 2019.

4. L. Russi, C. Moretti, L. Raggi, E. Albertini, and E. Falistocco: "Identifying commercially relevant Echinacea species by AFLP molecular markers." Genome. vol. 52, no. 11, pp. 912-918, 2009.

5. P. Kaushik, V. Yadav, G. Singh, R. Jha, and others: "Visiting Bael (Aegle marmelos) as a protective agent against COVID-19: A review." Indian Journal of Traditional Knowledge (IJTK). vol. 19, pp. S-153, 2021.

6. R. Gupta and P. Kaushik: "PhytoPotential of <em $>$ Allium cepa $</ \mathrm{em}>$ and $<\mathrm{em}>$ Allium sativum $</ \mathrm{em}>$." IntechOpen, 2021.

7. B. Barrett, M. Vohmann, and C. Calabrese: "Echinacea for upper respiratory infection." Journal of Family Practice. vol. 48, pp. 628-635, 1999.

I. Saini, J. Chauhan, and P. Kaushik: "Medicinal Value of Domiciliary Ornamental Plants of the Asteraceae Family." Journal of Young Pharmacists. vol. 12, no. 1, pp. 3, 2020. 
8. S. Sinha: "Ascertaining the Paradigm of Secondary Metabolism Enhancement through Gene Level Modification in Therapeutic Plants." Journal of Young Pharmacists. vol. 11, no. 4, pp. 337-343, 2019.

9. J. Barnes, L. A. Anderson, S. Gibbons, and J. D. Phillipson: "Echinacea species (Echinacea angustifolia (DC.) Hell., Echinacea pallida (Nutt.) Nutt., Echinacea purpurea (L.) Moench): a review of their chemistry, pharmacology and clinical properties." Journal of Pharmacy and Pharmacology. vol. 57, no. 8, pp. 929-954, 2005.

10. P. Kaushik, I. Andújar, S. Vilanova, M. Plazas, P. Gramazio, F. J. Herraiz, N.S. Brar, and J. Prohens: "Breeding vegetables with increased content in bioactive phenolic acids." Molecules. vol. 20, no. 10, pp. 18464-18481, 2015.

11. T. Kumar, B. Kumari, S. Arya, and P. Kaushik: "Effect of different spacings of Eucalyptus based agroforestry systems soil nutrient status and chemical properties in semi-arid ecosystem of India." Journal of Pharmacognosy and Phytochemistry. vol. 8, no. 3, pp. 18-23, 2019.

12. J. Chauhan, I. Saini, T. Kumar, and P. Kaushik: "Integrated Pest Management for Acacia: Prospects and Challenges.", 2020

13. K. M. Kumar and S. Ramaiah: "Pharmacological importance of Echinacea purpurea." International Journal of Pharma and Bio Sciences. vol. 2, no. 4, pp. 304-314, 2011.

14. G. S. Malhi, M. Kaur, P. Kaushik, M. N. Alyemeni, A.A. Alsahli, and P. Ahmad: "Arbuscular mycorrhiza in combating abiotic stresses in vegetables: An ecofriendly approach." Saudi Journal of Biological Sciences. vol. 28, no. 2, pp. 1465, 2021.

I. Saini, P. Kaushik, A. A. Al-Huqail, F. Khan, and M. H. Siddiqui: "Effect of the diverse combinations of useful microbes and chemical fertilizers on important traits of potato." Saudi Journal of Biological Sciences. 2021.

15. P. Bijalwan, K. Jeddi, I. Saini, M. Sharma, P. Kaushik, and K. Hessini: "Mitigation of Saline Conditions in Watermelon with Mycorrhiza and Silicon Application." Saudi Journal of Biological Sciences. 2021.

16. M. Sharma, I. Saini, P. Kaushik, M. M. Aldawsari, T. A. Balawi, and P. Alam: "Mycorrhizal fungi and Pseudomonas fluorescens application reduces root-knot nematode (Meloidogyne javanica) infestation in eggplant." Saudi Journal of Biological Sciences. vol. 28, no. 7, pp. 3685-3691, 2021.

17. P. Kaushik, O. S. Sandhu, N. S. Brar, V. Kumar, G. S. Malhi, H. Kesh, and I. Saini: "Soil Metagenomics: Prospects and Challenges." Mycorrhizal FungiUtilization in Agriculture and Industry. IntechOpen (2020).

A. Yadav, I. Saini, P. Kaushik, M. Ahmad Ansari, M. Rashid Khan, and N. Haq: "Effects of arbuscular mycorrhizal fungi and P-solubilizing Pseudomonas fluorescence (ATCC-17400) on morphological traits and mineral content of sesame." Saudi Journal of Biological Sciences. 2021.

18. Saini, A. Aggarwal, and P. Kaushik: "Influence of Biostimulants on Important Traits of Zinnia elegans Jacq. under Open Field Conditions." International Journal of Agronomy. vol. 2019, pp. e3082967, 2019.

19. Saini, A. Aggarwal, and P. Kaushik: "Inoculation with mycorrhizal fungi and other microbes to improve the morphophysiological and floral traits of Gazania rigens (L.) Gaertn." Agriculture. vol. 9, no. 3, pp. 51, 2019.

20. Saini, K. Rani, N. Gill, K. Sandhu, N. 
Bisht, T. Kumar, P. Kaushik, and others: "Significance of Arbuscular Mycorrhizal Fungi for Acacia: A Review." Pakistan Journal of Biological Sciences: PJBS. vol. 23, no. 10, pp. 1231-1236, 2020.

21. P. Kaushik and D. K. Saini: "Silicon as a vegetable crops modulator-A review." Plants. vol. 8, no. 6, pp. 148, 2019.

22. R. Kumar, D. K. Reddy, and P. Kaushik: "Effect of Silicon Application on Leaf mineral Composition of Eucalyptus." bioRxiv. 2021.

23. G. S. Malhi, M. Kaur, and P. Kaushik: "Impact of Climate Change on Agriculture and Its Mitigation Strategies: A Review." Sustainability. vol. 13, no. 3, pp. 1318, 2021.

24. M. Sharma, P. Kaushik, and P. Chaturvedi: "Enumeration, antagonism and enzymatic activities of microorganisms isolated from railway station soil." BioRxiv. pp. 454595, 2018.

25. P. Kaushik: "Classification of Indian States and Union Territories based on their Soil Macronutrient and Organic Carbon Profiles." bioRxiv. pp. 2020.02.10.930586, 2020.

26. M. B. Farhat, R. Chaouch-Hamada, J. A. Sotomayor, A. Landoulsi, and M. J. Jordán: "Antioxidant potential of Salvia officinalis L. residues as affected by the harvesting time." Industrial Crops and Products. vol. 54, pp. 78-85, 2014.

27. R. Re, N. Pellegrini, A. Proteggente, A. Pannala, M. Yang, and C. Rice-Evans: "Antioxidant activity applying an improved ABTS radical cation decolorization assay." Free radical biology and medicine. vol. 26, no. 9-10, pp. 1231-1237, 1999.

28. G. Mazza and T. Cottrell: "Volatile components of roots, stems, leaves, and flowers of Echinacea species." Journal of agricultural and food chemistry. vol. 47, no. 8, pp. 3081-3085, 1999.

29. M. Giovannetti and B. Mosse: "An evaluation of techniques for measuring vesicular arbuscular mycorrhizal infection in roots." New phytologist. pp. 489-500, 1980.

30. G. Araim, A. Saleem, J. T. Arnason, and C. Charest: "Root colonization by an arbuscular mycorrhizal (AM) fungus increases growth and secondary metabolism of purple coneflower, Echinacea purpurea (L.) Moench." Journal of Agricultural and Food Chemistry. vol. 57, no. 6, pp. 2255-2258, 2009.

31. M. Attarzadeh, H. Balouchi, M. Rajaie, M. M. Dehnavi, and A. Salehi: "Improving growth and phenolic compounds of Echinacea purpurea root by integrating biological and chemical resources of phosphorus under water deficit stress." Industrial Crops and Products. vol. 154, pp. 112763, 2020.

32. T. Kumar, K. Bhardwaj, and P. Kaushik: "Effect of soil properties and nutrient status on Eucalyptus tereticornis based agroforestry system in India." AgriXiv. vol. 9, no. 12, pp. 1-5, 2020.

\section{How to cite this article:}

Asha Sharma, Bandi Arpitha Shankar and Ishan Saini. 2021. Mycorrhizal Inoculation affects the Biochemical Composition of Echinacea. Int.J.Curr.Microbiol.App.Sci. 10(08): 51-57. doi: https://doi.org/10.20546/ijcmas.2021.1008.007 